\title{
Birth Defects: A Hospital Based Study in Chittagong, Bangladesh
}

\author{
Tahmina Banu* \\ Tanvir K Chowdhury \\ Sahadeb Kumar Das \\ Md Zonaid Chowdhury \\ Md Momtazul Hoque \\ M A Mushfiqur Rahman
}

Department of Pediatric Surgery

Chittagong Medical College

Chittagong 4000, Bangladesh.
*Correspondence to:

\section{Tahmina Banu}

Professor \& Head

Department of Pediatric Surgery

Chittagong Medical College \& Hospital

Chittagong 4000. Bangladesh.

Mobile : +8801711720635 Fax: +88031628185

E-mail : proftahmina@gmail.com

\begin{abstract}
Introduction: Birth defects are one of the most common causes of disability in developed and developing countries. Birth defects are structural or functional anomalies, including metabolic disorders, which are present at the time of birth. Although the worldwide incidence of birth defects is estimated at 3-7\%, the rate varies widely between countries. In this paper, we categorized the birth defects most commonly seen in Bangladesh and their outcome. We hope to use this information to guide the strategies used to manage these problems. Materials and Methods: This hospital based, descriptive study was done in the Department of Pediatric Surgery in Chittagong Medical College and Hospital from January 2008 to December 2012. Records of all patients with birth defects in our hospital and departmental database were reviewed. Types of birth defects, age, sex, surgery performed and outcome were analyzed in patients admitted during this period. Data were analyzed by SPSS 17. Statistical analysis was performed by the chi-square test and mean and percentage values were calculated. $\mathrm{P}<0.05$ was considered to be statistically significant. Results: During this five year period, there were 5661 patients of birth defects admitted in this department. Of these, 5156 had a single congenital anomaly and 505 had multiple congenital anomalies. The male to female ratio was 2.1: 1 . Birth defects comprised $44.61 \%$ of all Pediatric surgical admissions and $0.90 \%$ of total hospital admissions. The gastrointestinal system was the most common organ system involved, followed by the genitourinary system. Inguinal hernias were the most common gastrointestinal abnormality and hypospadias were the most common genitourinary case. A total of 3921 operations were performed for birth defects, representing $69.26 \%$ of total admission for birth defects. Most operations were done for gastrointestinal and genito-urinary defects. Inguinal herniotomy was the most commonly performed operation followed by laparotomy for various indications. There were 225 deaths for birth defects. While this is only $3.97 \%$ of all admissions for birth defects, this represents $51.49 \%$ of all (pediatric) deaths during the study period. The most common cause of death was anorectal malformations followed by gastroschisis. Conclusion: The study helps assess the burden of birth defects in the Bangladeshi society. There is a need for more extensive, nationwide screening studies to determine the birth prevalence, types and distribution of birth defects in Bangladesh.
\end{abstract}

Key words: Birth defect; Sex; Systemic distribution; Operations; Outcome.

\section{INTRODUCTION}

Birth defects have emerged as the major childhood health problem. Birth defects affect approximately 1 in 33 infants and are the fourth most common cause of neonatal deaths. The disease burden results in about 270000 neonatal deaths and about 3.2 million birth defect-related disabilities every year ${ }^{1}$. A birth defect is any alteration of a normal anatomic structure that is present at birth and has cosmetic, medical or surgical significance.

$w w w . c m \circ s h m c j . \circ r g$ 
It can be narrowly defined in terms of a malformation, an abnormality of physical structure or form usually found at birth or during the first few weeks of life; or defined more widely to include functional disturbances - any irreversible condition existing in a child before birth in which there is sufficient deviation in the usual number, size, shape, location or inherent character of any part, organ, cell or cell constituent to warrant its designation as abnormal ${ }^{2-3}$. The WHO defines a birth defect (also referred to as a congenital anomaly) as a structural or functional anomaly, including metabolic disorders, which are present at the time of birth ${ }^{1}$.

The etiology of the malformation can be divided into genetic (multifactorial, single gene, or chromosomal) factors, environmental factors, teratogens and unknown etiologies. Teratogens include maternal conditions such as alcoholism, diabetes, endocrinopathy, phenylketonuria, nutritional deficiency and infections; mechanical problems; chemical agents; drugs; radiation; hyperthermia, etc ${ }^{4-7}$. Approximately $50 \%$ of major anomalies have no recognized etiology and most have multi-factorial inheritance. It is estimated that $94 \%$ of serious birth defects occur in middle- and low-income countries, where mothers are more susceptible to macro- and micronutrient malnutrition and have increased exposure to perinatal infection and increased alcohol use during pregnancy. Advanced maternal age also increases the risk of chromosomal abnormalities such as Down syndrome $e^{4-8}$.

Although the worldwide incidence of birth defects is estimated at $3-7 \%$, the rate varies widely between countries ${ }^{9}$. It is reported to be $1.07 \%$ in Japan, $1.49 \%$ in South Africa, 2\% in England, 2$3 \%$ in USA and $4.3 \%$ in Taiwan. In India, the overall incidence of birth defects ranges from $0.3 \%$ to $3.6 \%$. These variations were suggested to be due to social, racial, ecological, and economical influences ${ }^{4}$.

In 2010, the World Health Assembly adopted a resolution to promote primary prevention and the health of children with birth defects. To achieve this aim, the assembly called for the development of registration and surveillance systems, with supplemental goals of developing body of expertise, strengthening research on aetiology, diagnosis and prevention and promoting international cooperation ${ }^{1}$. However, despite valiant efforts, many developing countries have no record system for birth defects and data on birth defects from population-based studies originating from developing countries are largely lacking.

Bangladesh is a densely populated country with a high growth rate of $1.37 \%$ a year ${ }^{10}$. Many babies are born without any antenatal evaluation and a significant amount of deliveries occur outside the hospital setting. Due to the lack of prenatal screening, maternal awareness of the problem and limited parental knowledge of resources available to them, babies with congenital anomalies never receive adequate medical follow up. If proper care can be given, the morbidity and mortality of birth defects can be reduced. Presently, there is no data available on the incidence of birth defects in Bangladesh or their predisposing factors. This study will attempt categorize birth defects most commonly seen in Bangladesh with the hope that this information can then be used to better prevent and manage birth defects on the country.

\section{MATERIALS \& METHODS}

This hospital based, descriptive, retrospective study was done in the Department of Pediatric Surgery, Chittagong Medical College Hospital $(\mathrm{CMCH})$ from January 2008 to December 2012. $\mathrm{CMCH}$ is the largest hospital with pediatric surgical facilities in the Chittagong district of Bangladesh. The hospital serves a catchment area with population of approximately 30 million people ${ }^{11}$. Records of all patients with birth defects in hospital and departmental database were reviewed. The types of birth defect, age, sex, surgery performed and outcome were assessed in patients admitted during this period. Comparisons were made between the total pediatric surgical admissions and total hospital admissions during this period. Stillborn babies with birth defects were excluded from this study. Data were analyzed by SPSS 17. Statistical analysis was performed by the chi-square test; mean and percentage values were calculated. $\mathrm{P}<0.05$ was considered to be statistically significant.

\section{RESULTS}

During this five year period, 5661 patients with birth defects were admitted to the Pediatric Surgery Department of $\mathrm{CMCH}$. Of these, 5156 had single congenital anomaly and 505 had multiple congenital anomalies. Birth defects comprised 44.61\% of all pediatric surgical admissions and $0.90 \%$ of total hospital admissions during this time period. Table-1 shows the percentage of pediatric surgical and total hospital admissions for each year of our study. Males had a higher frequency of congenital anomalies when compared to female (3837 vs. 1761) with a male to female ratio of 2.1: 1 . Table- 2 shows the gender distribution of birth defects and other pediatric surgical admissions.

Table 1 : Yearly Percentage of Pediatric Surgical and Total Hospital Admissions

\begin{tabular}{|c|c|c|c|c|c|}
\hline Year & $\begin{array}{l}\text { Number of } \\
\text { Birth } \\
\text { Defects }\end{array}$ & $\begin{array}{l}\text { Number of } \\
\text { Pediatric } \\
\text { Surgical } \\
\text { Admissions }\end{array}$ & $\begin{array}{l}\text { Percent of } \\
\text { Pediatric } \\
\text { Surgical } \\
\text { Admissions }\end{array}$ & $\begin{array}{l}\text { Total } \\
\text { Hospital } \\
\text { Admissions }\end{array}$ & $\begin{array}{l}\text { Percent of } \\
\text { Total Hospital } \\
\text { Admissions }\end{array}$ \\
\hline 2008 & 927 & 2012 & 46.07 & 111753 & 0.83 \\
\hline 2009 & 1298 & 2162 & 60.04 & 114830 & 1.13 \\
\hline 2010 & 1143 & 2470 & 46.28 & 130394 & 0.88 \\
\hline 2011 & 1164 & 2985 & 38.99 & 139424 & 0.83 \\
\hline 2012 & 1129 & 3060 & 36.90 & 132697 & 0.85 \\
\hline Total & 5661 & 12689 & 44.61 & 629098 & 0.90 \\
\hline
\end{tabular}

Table 2 : Birth defects by sex

\begin{tabular}{lccr} 
& $\begin{array}{c}\text { Number of Pediatric } \\
\text { Surgical admissions }\end{array}$ & $\begin{array}{c}\text { Number of } \\
\text { birth defects }\end{array}$ & Percentage \\
Male & 8306 & 3837 & 46.20 \\
Female & 4320 & 1761 & 40.76 \\
Ambiguous genitalia & 63 & 63 & 100 \\
Total patients & 12689 & 5661 & 20.18 \\
\hline $\mathrm{P}<0.05$ & & &
\end{tabular}

The gastrointestinal system was the most common organ system involved, followed by the genitourinary system. Inguinal hernias were the most common gastrointestinal abnormality and hypospadias were the most common genitourinary case. Table-3 shows the relative distribution of birth defects by organ systems. 
Table 3 : Systemic distribution of birth defects

\begin{tabular}{|c|c|c|c|c|c|}
\hline Gastrointestinal & 2548 & Genitourinary & 1779 & Vascular & 414 \\
\hline Inguinal hernia & 1121 & Hypospadias & 975 & Haemangioma & 251 \\
\hline ARM & 460 & PUV & 186 & Thalassemia with splenomegaly & 65 \\
\hline Malrotation & 86 & UDT & 169 & Cystic hygroma & 53 \\
\hline Intestinal Atresia & 72 & Phimosis & 139 & Vascular malformation & 29 \\
\hline Omphalocele & 68 & PUJO & 108 & Lymphangiohaemangioma & 9 \\
\hline IHPS & 64 & Ambiguous genitalia & 63 & Hemophilia & 4 \\
\hline Gastroschisis & 41 & Ectopiavesicae & 30 & Macrostoma & 3 \\
\hline Umbillical hernia & 36 & Neurogenic bladder & 16 & & \\
\hline Biliary atresia & 24 & Ectopic ureter & 14 & Orofacial & 440 \\
\hline Choledocal Cyst & 22 & Epispadias & 13 & Tongue tie & 144 \\
\hline Diaphragmatic hernia & 15 & Mega meatus intact prepuce & 7 & Cleft lip & 98 \\
\hline Ventral hernia & 13 & Torsion of penis & 6 & Cleft lip with palate & 94 \\
\hline Patent VID & 11 & Urogenital sinus anomaly & 6 & Cleft palate & 80 \\
\hline Eventration of diaphragm & 7 & Duplex urinary system & 5 & Preauricular skin tag & 24 \\
\hline Meckel's diverticulum & 7 & Vaginal tag & 4 & & \\
\hline midgut Volvulous & 2 & Ectopic kidney & 3 & Head and neck & 51 \\
\hline Para umbilical hernia & 2 & Horse shoe kidney & 3 & Meningocele & 18 \\
\hline Epigastric hernia & 1 & Renal agenesis & 2 & Myelomeningocele & 11 \\
\hline Antral web & 1 & Ectopic testis & 2 & Branchial fistula & 7 \\
\hline Meconium plug & 3 & $\begin{array}{l}\text { Ectopic testis } \\
\text {. }\end{array}$ & 2 & Enancephaly & 4 \\
\hline Meconium ileus & 3 & Polycystic kidney disease & 2 & Thyroglossal fistula & 4 \\
\hline \multirow[t]{3}{*}{ Dupliction cyst } & 2 & Ectopic penis & 1 & Lipomeningocele & 3 \\
\hline & & Patent Urachus & 2 & Thyroglossal Cyst & 3 \\
\hline & & Cobb's collar & 2 & Microcephaly & 1 \\
\hline Orthopedic & 61 & Uretrocele & 3 & & \\
\hline Syndactyly & 32 & urethral duplication & 1 & Skin and soft tissue & 93 \\
\hline Polydactyly & 22 & Torsion of penis & 3 & Dermoid & 86 \\
\hline club foot & 6 & VUJO & 9 & Sacrocoxygealteratoma & 4 \\
\hline cong.Hip dislocation & 1 & Micropenis & 5 & Amniotic band & 3 \\
\hline
\end{tabular}

Age of presentation varied among defects, with the youngest infants presenting with gastroschisis and omphaloceles and with oldest with hypospadias and thalassemia with splenomegaly. Figure-1 shows the age range with mean age at presentation and Table-4 shows the mean age at presentation of birth defects at different age groups.

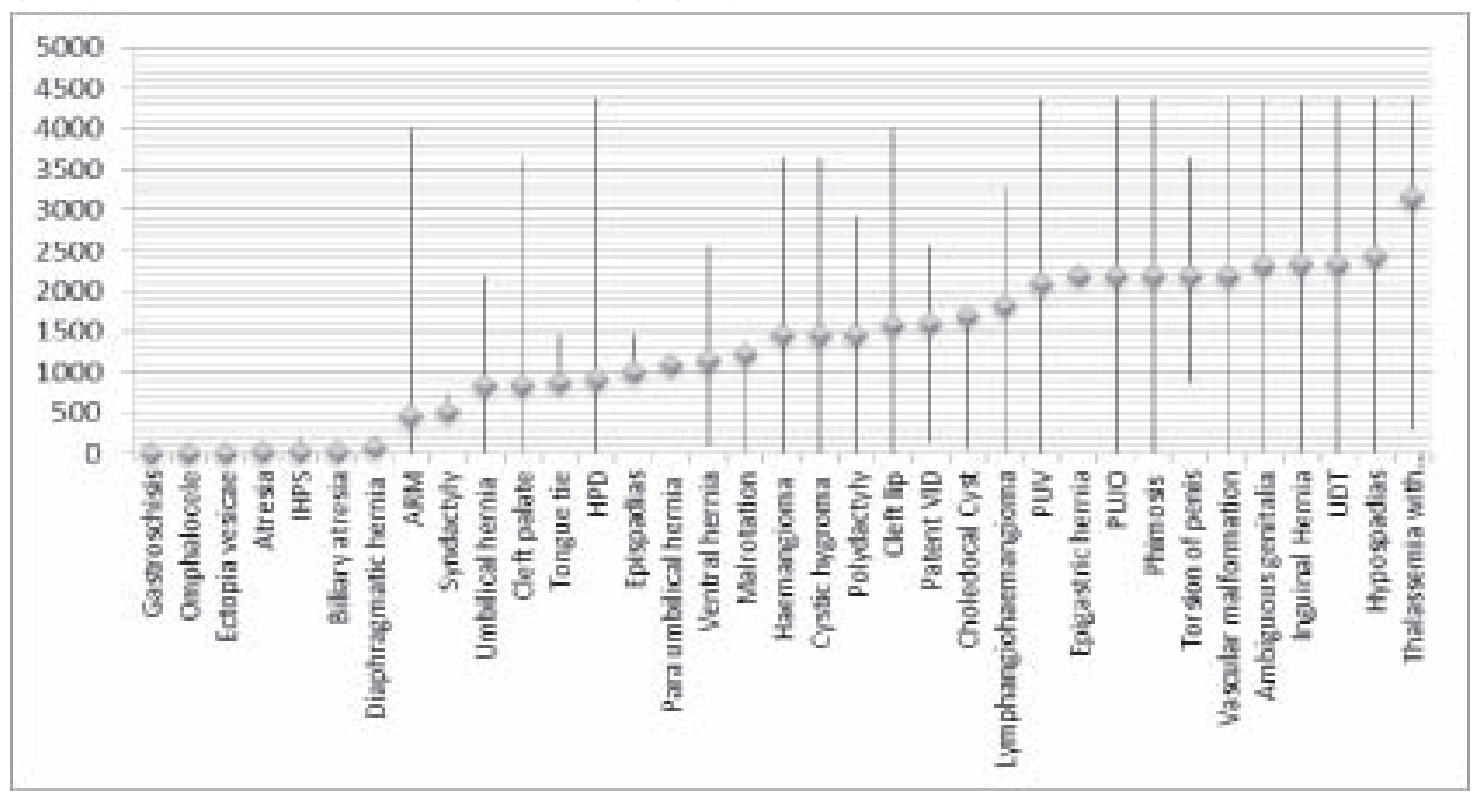

Figure 1 : Age range with mean age at presentation (Days) 
Table 4 : Mean age at presentation in different age groups

\begin{tabular}{|c|c|c|c|c|}
\hline $\begin{array}{l}\text { Neonate } \\
\text { Gastroschisis }\end{array}$ & $\begin{array}{l}28 \text { D-2 yr } \\
\text { Diaphragmatic } \\
\text { hernia }\end{array}$ & $\begin{array}{l}2-4 \text { yrs } \\
\text { Umbilical } \\
\text { hernia }\end{array}$ & $\begin{array}{l}4-6 \text { yrs } \\
\text { Cleft lip }\end{array}$ & $\begin{array}{l}6-8 \text { yrs } \\
\text { DSD }\end{array}$ \\
\hline Omphalocele & ARM & Cleft palate & Patent VID & Inguinal Hernia \\
\hline Ectopiavesicae & Syndactyly & Tongue tie & Choledocal Cyst & UDT \\
\hline Intestinal Atresia & & $\begin{array}{l}\text { Para umbilical } \\
\text { hernia }\end{array}$ & $\begin{array}{l}\text { Lymphangiohae } \\
\text { mangioma }\end{array}$ & $\begin{array}{l}\text { Thalassemia with } \\
\text { splenomegaly }\end{array}$ \\
\hline IHPS & & Epispadias & PUV & Hypospadias \\
\hline Biliary atresia & & $\begin{array}{l}\text { Hirschsprung's } \\
\text { disease } \\
\text { Ventral hernia } \\
\text { Malrotation } \\
\text { Haemangioma } \\
\text { Cystic hygroma } \\
\text { Polydactyly }\end{array}$ & $\begin{array}{l}\text { Epigastric } \\
\text { hernia } \\
\text { PUJ0 } \\
\text { Phimosis } \\
\text { Torsion of penis } \\
\text { Vascular } \\
\text { malformation }\end{array}$ & \\
\hline
\end{tabular}

A total of 3921 operations were done for birth defects, representing $69.26 \%$ of total admissions for birth defects and $13.98 \%$ of total pediatric surgical admission. These operations excluded mini OT procedures like repair of minor cuts, incision and drainage of small abscesses. Table- 5 shows the percentage of operations for birth defects and other causes.
Table 5 : Percentage of operations for birth defects and other causes

\begin{tabular}{cccr} 
Year & $\begin{array}{c}\text { Total } \\
\text { operations }\end{array}$ & $\begin{array}{c}\text { Operation for } \\
\text { birth defects }\end{array}$ & $\begin{array}{r}\text { Percent of } \\
\text { operations }\end{array}$ \\
\hline 2008 & 1171 & 630 & 53.8 \\
2009 & 1611 & 853 & 52.95 \\
2010 & 1456 & 836 & 57.42 \\
2011 & 1567 & 853 & 54.44 \\
2012 & 1483 & 749 & 50.51 \\
Total & 7288 & 3921 & 53.8 \\
\hline
\end{tabular}

Most operations were done for gastrointestinal and genitourinary defects. Inguinal herniotomy was the most commonly performed operation followed by laparotomy. Table6 shows the systemic distribution of all operations.

Table 6 : Operations done for birth defects

\begin{tabular}{lr} 
Gastrointestinal & 763 \\
Herniotomy & 226 \\
Laparotomy & 168 \\
Colostomy & 145 \\
Colostomy Closer & 126 \\
Trans anal pull through & 106 \\
Anoplasty & 102 \\
Secondary closure & 77 \\
Pyloromyotomy for IHPS & 69 \\
Ileostomy & 48 \\
PSARP & 37 \\
Correction of malrotation & 33 \\
Ileostomy closure & 32 \\
Mass closure of burst abdomen & 31 \\
Release of congenital bands & 26 \\
Repair of umbilical hernia & 25 \\
Redo Anoplasty & 176 \\
Others & \\
& \\
Orthopedic & 9 \\
Release of Syndactyly & 2 \\
Polydactyly Excision & \\
Skin and soft tissue & \\
Ganglion & \\
Epithelial tag & \\
Release of Amniotic band & 2 \\
\hline
\end{tabular}

$\begin{array}{lr}\text { Urinary } & 240 \\ \text { Cystoscopicfulgaration } & 236 \\ \text { Urethroplasty } & 160 \\ \text { Cystoscopic examination } & 130 \\ \text { Orchidectomy } & 50 \\ \text { A-H pyloplasty } & 36 \\ \text { Orthoplasty } & 33 \\ \text { Pyeloplasty } & 29 \\ \text { Repair of Urethral Fistula } & 19 \\ \text { Cutaneous Vesicostomy } & 18 \\ \text { Meatotomy } & 14 \\ \text { Uretertic reimplantation } & 13 \\ \text { Repair of bladder exstrophy } & 12 \\ \text { Suprapubiccystostomy } & 11 \\ \text { Nephrostomy } & 7 \\ \text { Ureteric reimplantation } & 5 \\ \text { Correction of Torsion penis } & 4 \\ \text { Orchiopexy } & 30\end{array}$

\section{Head \& Neck}

Branchial sinus

Branchial Fistula

Duplication of external auditory canal

Preauricular sinus

$\begin{array}{lr}\text { Vascular } & 53 \\ \text { Haemangioma Excision } & 46 \\ \text { Splenectomy } & 41 \\ \text { Cauterization } & 37 \\ \text { Sclerotherapy Hemangioma } & 33 \\ \text { Sclerotheapy Cystic hygroma } & 26 \\ \text { Hemangioma cauterization } & 12 \\ \text { Sclerotherapy } & 6 \\ \text { Radial ligation of Hemangioma } & 2 \\ \text { Lymphangiohemangioma } & 1 \\ \text { Diathermy cauterization } & 1 \\ \text { Ligature of bleeding hemangioma } & 1\end{array}$

$\begin{array}{lr}\text { Others } & \\ \text { Excision } & 283 \\ \text { Others } & 159 \\ \text { Laparoscopy } & 122 \\ \text { EUA } & 30 \\ \text { Diagnistic laparoscopy } & 7\end{array}$

$\begin{array}{lr}\text { Orofacial } & \\ \text { Release of Tongue Tie } & 125 \\ \text { Cheiloplasty } & 25 \\ \text { Pre auricular skin tag } & 21 \\ \text { Palatoplasty } & 17\end{array}$

There were 225 deaths for birth defects which is $51.49 \%$ of all Pediatric Surgical deaths during the study period, $3.97 \%$ of all admissions for birth defects, and $1.77 \%$ of all Pediatric surgical admissions. Out of these, neonatal deaths were $151(67.11 \%)$, infant mortality was $42(18.67 \%)$ and child mortality was 32(14.22\%).

Most common cause of death was ARM followed by Gastroschisis. Table-7 shows the systemic distribution of the deaths. 
Table 7 : Systemic distributions of Deaths

\begin{tabular}{lrlr} 
Gastrointestinal & 187 & Urinary & 27 \\
ARM & 46 & PUV & 23 \\
Gastroschisis & 30 & PBS & 1 \\
Intestinal atresia & 28 & PKD & 1 \\
Neonatal intestinal & & & \\
obstruction & 25 & PUJO & 2 \\
HPD & 17 & & 5 \\
Omphalocele & 16 & Vascular & 3 \\
CDH & 7 & Lymphangioma & 1 \\
Meconium Ileus & 5 & Hemangioma & 1 \\
Biliary atresia & 3 & Vascular malformation & 1 \\
IHPS & 3 & & 6 \\
TEF & 3 & Others & 3 \\
Choledochal cyst & 1 & Multiple birth defects & 3 \\
Congenital bands & 1 & Conjoint twin & 2 \\
Malrotation & 1 & Thorachoschisis & 1 \\
Midgut volvulus & 1 & & \\
\hline
\end{tabular}

\section{DISCUSSION}

In the present descriptive study of birth defects in the Chittagong district of Bangladesh, birth defects were $0.9 \%$ of total hospital admissions, similar to rates found on incidence studies. Birth defects comprised about $45 \%$ of all pediatric surgical admissions. We found a higher occurrence of birth defects in males than females, a finding that is in contrast to another study in Iran who reported no sex difference ${ }^{12}$. Birth defects occurred twice in male than in female. Many studies have documented male preponderance but Parmar et al noted a female preponderance?. With regard to pattern of birth defects in the study, the most common system involved was gastrointestinal $(45 \%)$ followed by genitourinary $(31.43 \%)$. This finding is consistent with reports from Asam by Dutta et ${ }^{12}$. However, it seems that this is not a universal trend. A study from Gujrat by Parmar et al reported that the central nervous system $(65 \%)$ was the most system followed by gastrointestinal tract (14\%) [9] and reports from Iran, Bahrain, Beirut and Maharashtra found the musculoskeletal system to be the most common system involved $^{13-15}$.

The most common gastrointestinal disease was inguinal hernia, which is different from reports in Iran, Asam and Jammu, India where ARM and Hirschsprung's disease were the most common. The findings that hypospadias was the most common genitourinary disease is consistent with reports from Iran and Jammu and different from Asam. The most common orthopedic disease was Syndactyly, which is different from reports from Jammu and Asam (club foot) and different from Iran (polydactyly). The most common vascular disease was hemangioma, and the most common oro-facial disease was tongue tie, which is different from other studies (cleft lip and palate) $)^{7,9,12-13}$.
The most common neurological disease was meningomyelocele, which is consistent with reports from Jammu but different from Iran (hydrocephalus) and Gujrat (anencephaly) which included still born babies. The orthopedic and neurosurgical cases are dealt with by separate departments and their data were not included in this study. We only recorded the cases which initially came to us and were managed by our department or referred to respective discipline.

Mean age at presentation showed 4 groups when plotted on a graph with group 1 presenting in the neonatal period, group 2 presenting around 500 days (1.4 yrs), group 3 presenting around 1200 days (3.3 yrs) and group 4 around 2000 days (5.5 yrs). Admissions and operations for birth defects varied among years which did not show any linear increase as shown by another study. Operations for birth defect made up more than half $(53 \%)$ of all operations done during the study period. Prevention of birth defects will reduce a huge operative burden of birth defects. Although CDC reported that most birth defects are found within the first year of life, in this study only $1 / 4^{\text {th }}$ patients presented before their first year of life and mostly with more serious defects ${ }^{16}$. Birth defects were a major cause $(52 \%)$ of deaths during the study period. About $4 \%$ of patients admitted for birth defects died of their disease. Neonatal deaths were much higher, representing $67 \%$ of cases that died of a birth defect. The reason for this may be because younger infants presented with more serious diseases and $\mathrm{CMCH}$ currently lacks a neonatal intensive care unit and other supports for proper neonatal care. Unfortunately, $\mathrm{CMCH}$ is representative of most hospitals in the country where there are minimal systems or supports designed for early life intervention and care. Most common cause of death was ARM followed by Gastroschisis, the outcome of these defects is more favorable in developed countries.

Every 4.5 minutes, a baby is born with a birth defect. ${ }^{16}$ WHO is working with the US Centers for Disease Control and Prevention's (CDC) National Center on Birth Defects and Developmental Disabilities and other partners for the prevention of birth defects. The Global Strategy for Women's and Children's Health, launched in 2010 by the UN in collaboration with leaders from governments and other organizations like WHO and UNICEF is crucial to be implemented to improve neonatal and child health.

The International Clearinghouse for Birth Defects Surveillance and Research, which is a voluntary non-profit international organization in official relations with WHO, conducts birth defect surveillance and research programs from around the world in order to investigate and prevent birth defects. Prevention of birth defects will obviously reduce a huge burden on surgical care and ensure better health for the younger generation.

\section{CONCLUSION}

The study helps define the burden of birth defects in the Chittagong district of Bangladesh. There is a need for more extensive, nationwide screening studies to determine the birth prevalence, types and distribution of birth defects in Bangladesh.

\section{DISCLOSURE}

All the authors declared no competing interest. 
REFERENCES

1. Congenital anomalies. Anonymus. WHO.2012. (http://www.who.int/mediacenter/factsheets/fs370/en/) Accessed, 26.06.2013

2. Hudgins L, Cassidy S B. In Martin RJ, Fanroff AA, Walsh MC (eds). Congenital anomalies. Neonatal -Perinatal Medicine. 8th (edn), Philadelphia, Mosby- Elsivier. 2006; 561-581.

3. Ali A, Shafikhani Z, Abdulahi M. Congenital malformations among live births at Arvand Hospital Ahwaz, Iran - A Prospective study . Pak J Med Sci. 2008; 24: 33-37.

4. Tomatir A G, Demirhan H, Sorkun H C, Köksal A, Ozerdem F, Cilengir N. Major congenital anomalies: a five-year retrospective regional study in Turkey. Genetics and Molecular Research 2009; 8 (1): 19-27.

5. Harris JA, James L. State-by-state cost of birth defects: 1992. Teratology. 1997; 56(1-2): 11-16.

6. Botto LD, Lynberg MC, Erickson JD. Congenital heart defects, maternal febrile illness, and multivitamin use: a population- based study. Epidemiology. 2001; 12(5): 485-490.

7. Karbasi SA, Golestan M, Fallah R, Mirnaseri F, Barkhordari K, Mahdokht SB. Prevalence of Congenital Malformations in Yazd (Iran). ActaMedicaIranica. 2009; 47(2): 149-153.

8. EUROCAT Working Group (2002). Surveillance of congenital anomalies in Europe 1980-1999. EUROCAT Report 8. Universty of Ulster, Belfast.

9. Parmar A, Rathod S P, Patel S V, Patel S M. A study of congenital anomalies in newborn. NJIRM. 2010;1(1):13-17

10. Bangladesh population and housing census 2011.(http://www.bbs.gov.bd) Accessed 26.06.2013.

11. Bangladesh Bureau of Statistics (2011) Population \& housing census 2011. http://www.bbs.gov.bd/WebTestApplication/userfiles/Image/Census2011/Bangladesh_glance.pdf. Accessed 21 July 2012.

12. Dutta H K, Bhattacharyya N C, Sarma J N, Giriraj K J. Congenital malformations in Asam. J Indian Assoc Pediatr Surg. 2010; 15(2): 53-55.

13. Al Arrayed SS. Epidemiology of congenital abnormalities in Bahrain. East Mediterr Health J. 1995; 1(2): 248-252.

14. Dutta V, Chaturvedi P. Congenital malformations in rural Maharashtra. Indian Pediatr. 2000; 37(9): 998-1001.

15. Bittar Z. Major congenital malformations presenting in the first 24 hours of life in 3865 consecutive births in south of Beirut; Incidence and pattern. J Med Liban. 1998; 46(5): 256-260.

16. Birth Defect. Centers for disease control and prevention. Available at (http://www.cdc.gov/ncbddd/birthdefects/facts.html) Accessed 05.08.2013. 